\title{
Neointimal Macrophages Colocalize with Extracellular Matrix Gene Expression in Human Atherosclerotic Pulmonary Arteries
}

\author{
Michael J. Liptay, ${ }^{\ddagger}$ William C. Parks, * Robert P. Mecham, ${ }^{\star 3}$ Jill Roby, ${ }^{\star}$ Larry R. Kaiser, ${ }^{\star}$ Joel D. Cooper, ${ }^{\star}$ \\ and Mitchell D. Botney * \\ Departments of * Medicine, ${ }^{\ddagger}$ Surgery, and ${ }^{\S}$ Cell Biology, Jewish Hospital, Washington University Medical Center, \\ St. Louis, Missouri 63110
}

\begin{abstract}
Vascular remodeling in adult atherosclerotic pulmonary arteries is characterized by discrete areas of neointimal extracellular matrix gene expression, suggesting regulation by local factors. Though the factors responsible for inducing matrix gene expression in atherosclerotic lesions are largely unknown, several observations suggest macrophages may be a focal source of those factors.

Immunohistochemistry confirmed the presence of macrophages in the neointima of atherosclerotic elastic pulmonary arteries from patients with unexplained pulmonary hypertension. Areas of neointima containing dense clusters of macrophages were separated by sparsely populated areas. Foamy macrophages resided more deeply within the neointima than nonfoamy macrophages, which were found more often subjacent to the endothelium or within the lumenal one-third of the neointima. Combined immunohistochemistry-in situ hybridization indicated neointimal fibronectin and type I procollagen gene expression was intimately associated only with nonfoamy neointimal macrophages.

These observations suggest that: $(a)$ nonfoamy neointimal macrophages participate in the local regulation of extracellular matrix gene expression in atherosclerotic pulmonary arteries; (b) foamy macrophages, which are not associated with matrix gene expression, have undergone modulation of their secretory phenotype. (J. Clin. Invest. 1993. 91:588-594.) Key words: vascular remodeling • atherosclerosis • pulmonary hypertension - macrophages • extracellular matrix
\end{abstract}

\section{Introduction}

Macrophages constitute a significant proportion of the cells present in human atherosclerotic lesions (1-3) as well as lesions found in hypercholesterolemic animal models of atherogenesis $(4,5)$. They are derived from blood monocytes which adhere to the vascular endothelium and subsequently migrate into the subendothelial intima $(5,6)$. Within the neointima, these macrophages may contribute to lesion formation and progression by synthesizing several growth and differentiation factors. For example, analysis of human carotid atherosclerotic

Address correspondence to Mitchell Botney, M. D., Respiratory and Critical Care Division, Jewish Hospital, 216 S. Kingshighway Blvd., St. Louis, MO 63110.

Received for publication 24 April 1992 and in revised form 20 July 1992

J. Clin. Invest.

(c) The American Society for Clinical Investigation, Inc. 0021-9738/93/02/0588/07 \$2.00

Volume 91, February 1993, 588-594 lesions indicates a correlation between the levels of PDGF-B mRNA and c- $f m s$ mRNA, a macrophage-specific marker, indirectly suggesting PDGF-B is produced by macrophages (7). More directly, IL-1 protein and mRNA (8) and PDGF-BB protein (9) are detectable in macrophages within atherosclerotic plaques from cynomolgus monkeys. Although macrophages and their secreted products may be present within atherosclerotic lesions, the extent to which macrophages contribute to lesion formation and progression is unknown.

The pathogenesis of atherosclerosis includes the abnormal production of extracellular matrix proteins by neointimal smooth muscle cells. Several factors secreted by macrophages $(10,11)$ are capable of stimulating extracellular matrix protein synthesis. TGF- $\beta_{1}$ stimulates production of fibronectin (12, $13)$, collagen $(14,15)$, and tropoelastin $(16,17)$. IGF induces the synthesis of tropoelastin (18-20), and type I collagen (21). Interleukin-1 $(22,23)$ and tumor necrosis factor also induce type I collagen synthesis. Finally, PDGF (24), EGF (24), 1,25 dihydroxyvitamin $\mathrm{D}_{3}(25)$, and $\gamma$-interferon (26) all stimulate fibronectin synthesis. Thus, macrophages may contribute to the formation or progression of atherosclerotic lesions by inducing neointimal extracellular matrix production.

Lobar pulmonary arteries from patients with severe unexplained pulmonary hypertension are grossly atherosclerotic, characterized by a thick, concentric neointima (27). Normotensive vessels do not have a hyperplastic neointima. Immunohistochemistry shows elastin, type I collagen, and fibronectin proteins present diffusely throughout the neointima of hypertensive vessels. However, by in situ hybridization, neointimal cells expressing extracellular matrix genes are found in discrete clusters. Such focal extracellular matrix gene expression suggests regulation by local factors.

The purpose of these studies was to begin defining the role of macrophages in the progression of atherosclerotic lesions by determining the spatial relationship between neointimal macrophages and extracellular matrix gene expression in human atherosclerotic pulmonary arteries.

\section{Methods}

\section{Tissue}

Lobar pulmonary arteries were obtained from the excised lungs of seven patients undergoing single lung transplant surgery for unexplained pulmonary hypertension at Washington University Medical Center. Immediately after surgical resection, lobar pulmonary arteries from transplant recipients were processed for histological study and in situ hybridization.

\section{Immunohistochemistry}

Lobar pulmonary artery segments were fixed in $4 \%$ buffered formaldehyde for $6 \mathrm{~h}$ at room temperature and subsequently dehydrated in sequential 30,50, and $70 \%$ ethanol washes. Tissues were embedded in paraffin and prepared for immunoperoxidase staining as described pre- 
viously (27). Endogenous peroxidase was blocked with $0.3 \%$ ( $\mathrm{vol} / \mathrm{vol}$ ) $\mathrm{H}_{2} \mathrm{O}_{2}$ in methanol for $20 \mathrm{~min}$ at room temperature. Nonspecific immunoglobulin-binding sites were blocked with $2 \%$ BSA (Sigma Immunochemicals, St. Louis, MO), porcine sodium heparin $(5 \mathrm{mg} / \mathrm{ml})$ (Sigma), $0.5 \%$ (wt $/ \mathrm{vol}$ ) dithiothreitol (Sigma), and $0.3 \%$ (vol $/ \mathrm{vol}$ ) Triton X-100 (Sigma) for $1 \mathrm{~h}$ at $4^{\circ} \mathrm{C}$. Sections were subsequently incubated overnight at $4^{\circ} \mathrm{C}$ with HAM56, a mouse antimacrophage monoclonal antibody that may also cross-react with endothelial cells (a generous gift of Dr. A. Gown, University of Washington, Seattle, WA) (1). Normal mouse serum served as a negative control. Sections were then incubated for $30 \mathrm{~min}$ with affinity-purified biotin-conjugated goat anti-mouse IgM ( $1: 1,600$ dilution ), washed, and incubated for $30 \mathrm{~min}$ with horseradish peroxidase-streptavidin (1:400 dilution). Immunoglobulin complexes were then visualized by incubation with 3,3'diaminobenzidine $(0.5 \mathrm{mg} / \mathrm{ml}$ in $50 \mathrm{mM}$ Tris- $\mathrm{HCl}, \mathrm{pH} 7.4), 0.1 \%$ $\mathrm{H}_{2} \mathrm{O}_{2}$ and $\mathrm{NiCl}_{2}$. Sections were washed, counterstained with Harris hematoxylin, dehydrated, mounted in Permount, and examined by light microscopy.

\section{Immunohistochemistry-in situ hybridization}

Immunohistochemistry. Immunohistochemistry was performed as described above with several modifications to prevent RNA degradation. Aqueous solutions and glassware were treated with diethylpyrocarbonate (Sigma) and autoclaved. Nonspecific binding sites were inhibited with the blocking solution described above but including RNasin (4 $\mathrm{U} / \mathrm{ml}$ ) (Promega Corp., Madison, WI). HAM56 was diluted 1:4,000 with PBS, pH 7.5, containing $1 \%$ (wt/ vol) BSA and porcine sodium heparin $(10 \mathrm{mg} / \mathrm{ml})$. Sections were incubated overnight at $4^{\circ} \mathrm{C}$ with either HAM56 or normal mouse serum containing heparin $(10 \mathrm{mg} /$ $\mathrm{ml}$ ). RNasin was not added to the primary antibody solution due to the destabilizing effects of DTT present in the buffer. After conjugation with horseradish peroxidase-streptavidin ( $1: 400$ dilution), an intensification step was performed to preserve immunostaining during in situ hybridization (28). Sections were washed with $0.1 \mathrm{M}$ sodium acetate ( $\mathrm{pH}$ 6.0), incubated in $1 \%$ cobalt acetate in $0.1 \mathrm{M} \mathrm{NaOAc}$ ( $\mathrm{pH} \mathrm{6.0)}$ ) for $10 \mathrm{~min}$, and rewashed in $0.1 \mathrm{M} \mathrm{NaOAc}$. The sections were then incubated with $3,3^{\prime}$-diaminobenzidine $(0.5 \mathrm{mg} / \mathrm{ml}$ in $50 \mathrm{mM}$ Tris- $\mathrm{HCl}, \mathrm{pH}$ 7.4) and $0.1 \% \mathrm{H}_{2} \mathrm{O}_{2}$ for 2-7 min, washed three times in PBS for $5 \mathrm{~min}$, and stored in $95 \%$ ethanol for subsequent in situ hybridization. Immunohistochemical staining was evaluated before performing in situ hybridization.

In situ hybridization. ${ }^{35} \mathrm{~S}$-labeled human fibronectin ( $\mathrm{pFH}-6$ ) (gift of Dr. A. Kornblihtt, Institute for Studies in Genetic Engineering and Molecular Biology, Buenos Aires, Argentina) and type I procollagen (Hf677) cRNA probes were prepared with $\alpha-{ }^{35} \mathrm{~S}-\mathrm{UTP}(>1,200 \mathrm{Ci} /$ mmol, ICN Biochemicals, Irvine, CA) as described (29). pFH-6 is complementary to the first four type I repeats of fibronectin mRNA (30). Hf677 is complementary to the $\mathrm{COOH}$-terminal propeptide region of $\alpha \mathrm{I}(\mathrm{I})$ procollagen mRNA (31). ${ }^{35} \mathrm{~S}$-labeled T66, a 500-nucleotide sense RNA probe transcribed from a bovine tropoelastin cDNA, served as a negative control. This RNA is $68 \%$ guanosine-cytosine-rich and should have a propensity for nonspecific hybridization. Therefore, lack of in situ hybridization signal with this probe indicates appropriately stringent wash conditions.

In situ hybridization was performed essentially as previously described (27). Immunohistochemically stained sections were incubated with ${ }^{35}$ S-labeled pFH-6 or Hf677 antisense RNA probes. As controls, some sections were treated with $100 \mu \mathrm{g} / \mathrm{ml} \mathrm{RNase} \mathrm{A} \mathrm{(Sigma)} \mathrm{to} \mathrm{re-}$ move endogenous RNA. Sections were pretreated with $1 \mu \mathrm{g} / \mathrm{ml} \mathrm{nu}-$ clease-free proteinase $\mathrm{K}$ (Sigma) for $12 \mathrm{~min}$ rather than 30-45 min. This minimized loss of immunoreactive staining without sacrifice in subsequent in situ hybridization signal.

Hybridization solution containing $2.5 \times 10^{5} \mathrm{cpm}$ of ${ }^{35} \mathrm{~S}$-labeled probe was added to the processed sections and slides were incubated overnight at $55^{\circ} \mathrm{C}$. After hybridization, slides were washed extensively under stringent conditions. To decrease background, slides were incubated with $20 \mu \mathrm{g} / \mathrm{ml}$ RNase A to remove unhybridized probe. Washed slides were then processed for autoradiography.

\section{Results}

Macrophages were found in the neointima and adventitia of atherosclerotic lobar pulmonary arteries but were not observed within the medial layer (Fig. $1 \mathrm{~A}$ ). Within the neointima, focal collections of macrophages were observed, separated by areas of neointima containing few macrophages. The size of these dense collections of macrophages varied between patients. In contrast to the neointima, macrophages appeared randomly within the adventitia and no focal collections were observed.

Two populations of neointimal macrophages were clearly identified (Fig. 1, $B$ and $C$ ). Many macrophages contained lucent vacuoles in their cytoplasm and resembled lipid-laden macrophages. These foam cells tended to be found in clusters deeper within the neointima. A second population of small, nonfoamy macrophages with a small rim of cytoplasm surrounding the nucleus were observed more frequently within the lumenal inner third of the neointima. In addition, an intermediate population of macrophages were observed, larger than nonfoamy macrophages but containing few, if any, vacuoles. These intermediate-sized cells were found throughout the macrophage clusters and may be cells in transition between small, nonfoamy, and large, foamy macrophages.

A prerequisite for macrophage participation in local regulation of extracellular matrix protein synthesis is colocalization of neointimal macrophages and matrix synthesizing cells. To evaluate the spatial relationship between macrophages and cells expressing matrix genes, sequential immunohistochemistry-in situ hybridization was performed with tissue sections from three patients with unexplained pulmonary hypertension. Sequential immunohistochemistry-in situ hybridization, compared with in situ hybridization alone, indicated minimal attenuation of the autoradiographic signal in sections treated with either HAM56 or normal mouse serum (data not shown). Focal fibronectin gene expression was again observed in the neointima. Small and intermediate sized, nonfoamy macrophages were found in close proximity to cells with a positive in situ hybridization signal for fibronectin in all three patients (Fig. 2). Large, foamy macrophages with extensive cytoplasmic vacuoles were not associated with fibronectin gene-expressing cells. Although macrophages can synthesize fibronectin in vitro (32) and in vivo (33), we did not observe any macrophages expressing fibronectin mRNA. Control studies, with ${ }^{35}$ S-labeled sense T66 RNA, were negative (data not shown).

To confirm an intimate association between neointimal cells expressing extracellular matrix genes and macrophages, immunohistochemistry-in situ hybridization was performed with an ${ }^{35}$ S-labeled Hf677 cRNA probe. Procollagen gene expression was limited to the neointima. Macrophages were again closely associated with cells expressing type I procollagen mRNA (Fig. 3). Smooth muscle cells near the smaller nonfoamy macrophages again demonstrated strong in situ hybridization signal for procollagen mRNA, whereas cells near large foamy macrophages were negative.

\section{Discussion}

Previous observations suggested vascular remodeling in patients with severe pulmonary hypertension undergoing lung transplantation differed from remodeling in animal models of pulmonary hypertension (27). Marked medial hypertrophy accompanied by increased connective tissue synthesis and deposi- 

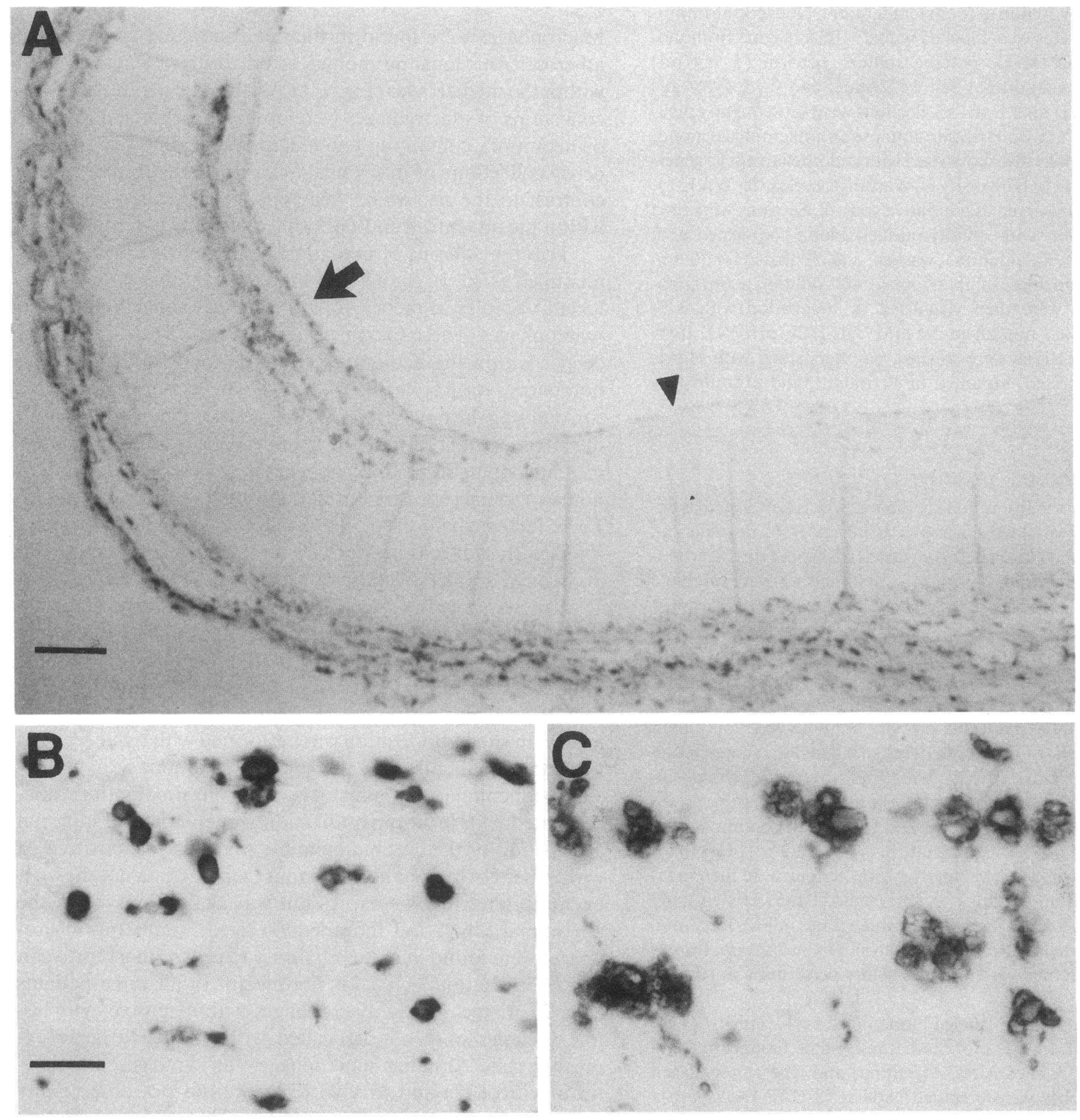

Figure 1. Macrophages are present as discrete clusters in the neointima. Human lobar pulmonary arteries from patients with pulmonary hypertension undergoing unilateral pulmonary transplantation were resected, fixed in $4 \%$ buffered formaldehyde, and embedded in paraffin. Immunohistochemistry was performed with HAM56, a mouse antimacrophage monoclonal antibody. $(A)$ Neointimal macrophages are found in clusters separated by areas with few macrophages $(\times 40)$. In the same patient, small nonfoamy macrophages $(B)$ and larger, foamy macrophages $(C)$ are clearly identified $(\times 200)$.

tion in the proximal pulmonary arteries, rather than diffuse intimal thickening or atherosclerosis, is observed in several animal models of hypoxic pulmonary hypertension $(29,34-38)$. Multiple factors may account for these differences between animal models of pulmonary hypertension and patients with severe pulmonary hypertension including age and species differences or duration and severity of hypertension. The presence of macrophages within the neointima and their association with extracellular matrix gene expression indicates another difference between vascular remodeling in adult patients and animal models, further suggesting different mechanisms may be involved. Vascular smooth muscle cells are the source of factors inducing matrix protein synthesis in a calf model of hypoxic pulmonary hypertension (38), whereas the intimate association between extracellular matrix gene expression and neointimal macrophages suggests these macrophages may be a source of factors inducing matrix protein synthesis in adult patients. However, in addition to stimulating extracellular matrix synthesis, many growth factors are mitogenic and chemotactic. Whether PDGF, IL-1, or other macrophage-derived factors colocalize to areas of extracellular matrix gene expression or, instead, are associated with neointimal cell proliferation or migration, requires further studies.

Many factors secreted by macrophages $(10,11)$ are capable of stimulating extracellular matrix protein synthesis including TGF- $\beta_{1}$, PDGF, IGF, and IL-1. The presence of IL-1 and 

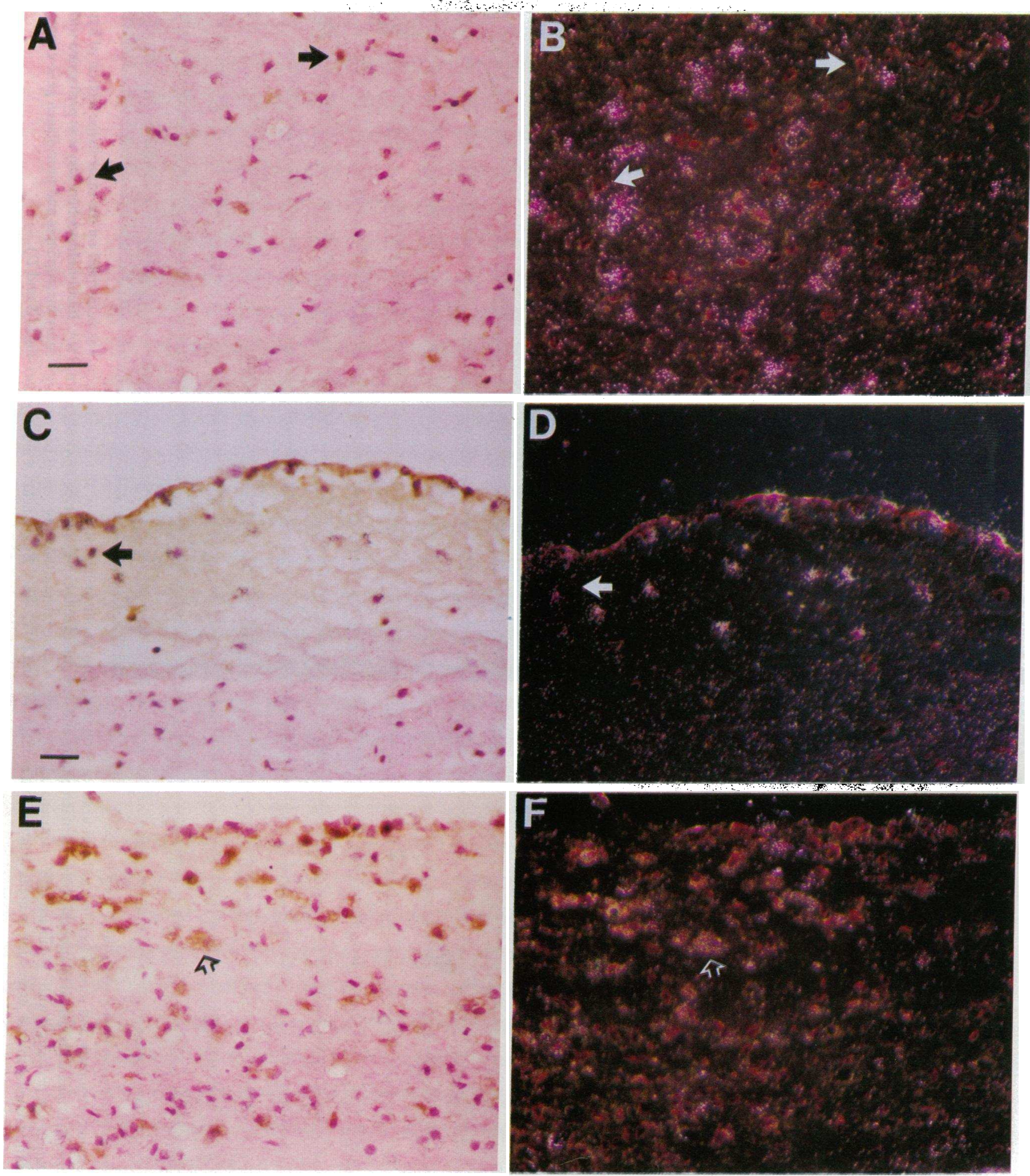

Figure 2. Macrophage immunohistochemistry and fibronectin in situ hybridization. Sequential immunohistochemistry-in situ hybridization was performed on the same tissue section of hypertensive lobar pulmonary arteries to evaluate the spatial relationship between macrophages and neointimal cells expressing fibronectin mRNA. Immunohistochemistry was performed with HAM 56 and in situ hybridization was performed with ${ }^{35}$ S-labeled pFH-6 antisense cRNA probe. Macrophages are stained brown on bright-field microscopy $(A, C$, and $E)$ and cells with a positive autoradiographic signal for fibronectin mRNA are seen on dark-field microscopy ( $B, D$, and $F$ ). A close relationship is observed between nonfoamy macrophages and fibronectin gene expression $(A$ and $B)(\times 400)$. Fibronectin gene expression does not colocalize with foamy macrophages $(E$ and $F)(\times 400)$. There is little fibronectin gene expression in areas with few macrophages. The few cells with a positive autoradiographic signal for fibronectin mRNA are associated with macrophages $(C$ and $D)(\times 200)$. Cross-reactivity between HAM 56 and endothelial cells is seen $(C)$. 


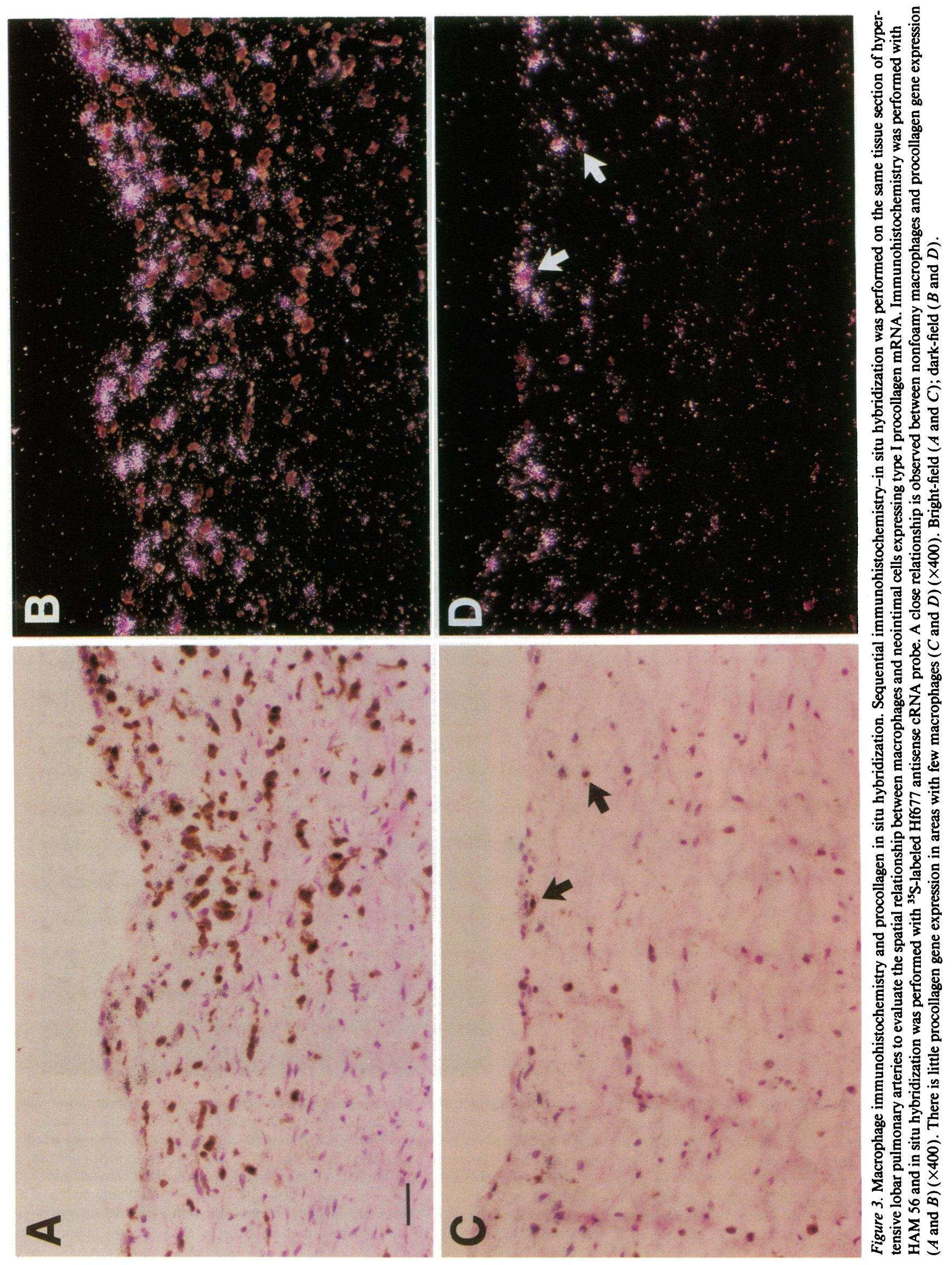


PDGF-BB in neointimal macrophages $(8,9)$ suggests these factors could be stimulating matrix synthesis in remodeling vessels. The presence of immunoreactive PDGF-BB protein only in non-lipid-laden macrophages (9) is consistent with our observation of a close association between small nonfoamy macrophages and matrix gene expression. The association of matrix gene expression around nonfoamy macrophages suggests that neointimal macrophages do not have a single, uniform phenotype but, rather, undergo modulation by the local milieu. Our results also indicate that macrophage subpopulations, distinguishable by different morphologies, have different secretory phenotypes and biological activities.

The atherosclerotic neointima contains both smooth muscle cells and macrophages (1-3). Sequential immunohistochemistry-in situ hybridization allows identification of the cells expressing extracellular matrix genes. The absence of fibronectin in situ hybridization signal in neointimal macrophages indicates these cells are not synthesizing fibronectin since mononuclear phagocyte fibronectin synthesis parallels fibronectin mRNA steady-state levels (32). This contrasts with increased fibronectin gene expression and synthesis by tissue macrophages isolated from patients with inflammatory diseases compared to normal alveolar macrophages (33). The difference between alveolar and neointimal macrophage fibronectin gene expression suggests there is no single inflammatory macrophage phenotype and again indicates modulation by the local milieu. Type I procollagen gene expression was also confined to nonmacrophage neointimal cells. Since procollagen gene expression correlates with cells actively synthesizing procollagen (Botney, M. D., M. J. Liptay, L. R. Kaiser, J. D. Cooper, W. C. Parks, and R. P. Mecham, manuscript submitted for publication), the present observations confirm earlier observations that neointimal smooth muscle cells are the source of type I procollagen (27).

How peripheral blood monocytes are recruited to specific sites within the neointima is unknown. Monocyte chemoattractant proteins have been detected in human and rabbit atherosclerotic lesions, particularly in macrophage-rich inflammatory regions $(39,40)$. However, degradation products of fibronectin (41), elastin (42), and collagen (43) have chemotactic properties that may also promote migration of macrophages to areas of local matrix synthesis. Once recruited, macrophage adherence to extracellular matrix proteins may induce cytokine synthesis and secretion (44). Thus, previously synthesized matrix proteins may contribute to further neointimal extracellular matrix protein synthesis by participating in macrophage recruitment and activation.

In summary, vascular remodeling in adult patients with severe unexplained pulmonary hypertension is characterized by focal extracellular matrix protein gene expression and a mononuclear infiltrate. An intimate association between these neointimal mononuclear cells and matrix gene expression was established by sequential immunohistochemistry-in situ hybridization. In addition, the technique identified neointimal smooth musclelike cells, and not mononuclear cells, as the matrix expressing cells. These observations illustrate the potential of sequential immunohistochemistry-in situ hybridization for providing additional insights into mechanisms of vascular remodeling in pulmonary hypertension.

\section{Acknowledgments}

The authors thank D. Stewart, Histology Technologist, for expert technical assistance.
This work was supported by grants HL-29594 and HL-02425 from the National Institutes of Health. M. D. Botney is a recipient of a Physician-Scientist award from the National Institutes of Health.

\section{References}

1. Gown, A., T. Tsukuda, and R. Ross. 1986. Human atherosclerosis. II. Immunocytochemical analysis of the cellular composition of human atherosclerotic lesions. Am. J. Pathol. 125:191-207.

2. Aqel, N. M., R. Y. Ball, H. Waldmann and M. J. Mitchison. 1985. Identification of macrophages and smooth muscle cells in human atherosclerosis using monoclonal antibodies. J. Pathol. 146:197-204.

3. Jonasson, L., J. Holm, O. Skalli, G. Bondjers, and G. K. Hansson. 1986. Regional accumulation of $\mathrm{T}$ cells, macrophages, and smooth muscle cells in the human atherosclerotic plaque. Arteriosclerosis. 6:131-138.

4. Gerrity, R. G., H. K. Naito, M. Richardson, and C. J. Schwartz. 1979. Dietary induced atherogenesis in swine: morphology of the intima in prelesion stages. Am. J. Pathol. 95:775-786.

5. Gerrity, R. G. 1981. The role of the monocyte in atherogenesis. II. Migration of foam cells from atherosclerotic lesions. Am. J. Pathol. 103:191-200.

6. Faggiotto, A., R. Ross, and L. Harker. 1984. Studies of hypercholesterolemia in the nonhuman primate. I. Changes that lead to fatty streak formation. Arterioclerosis. 4:323-340.

7. Barrett, T. B., and E. P. Benditt. 1988. Platelet-derived growth factor gene expression in human atherosclerotic plaques and normal artery wall. Proc. Natl. Acad. Sci. USA. 85:2810-2814.

8. Moyer, C. F., D. Sajuthi, H. Tulli, and J. K. Williams. 1991. Synthesis of IL-1 alpha and IL-1 beta by arterial cells in atherosclerosis. Am. J. Pathol. 138:951-960.

9. Ross, R., J. Masuda, E. W. Raines, A. M. Gown, S. Katsuda, M. Sasahara, L. T. Malden, H. Masuko, and H. Sato. 1990. Localization of PDGF-B protein in macrophages in all phases of atherogenesis. Science (Wash. DC). 248:10091012.

10. Takemura, R., and Z. Werb. 1984. Secretory products of macrophages and their physiological functions. Am. J. Physiol. 246:CI-C9.

11. Nathan, C. F. 1987. Secretory products of macrophages. J. Clin. Invest. 79:319-326

12. Ignotz, R. A., T. Endo, and J. Massague. 1987. Regulation of fibronectin and type I collagen mRNA levels by transforming growth factor- $\beta$. J. Biol. Chem. 262:6443-6446.

13. Ignotz, R. A., and J. Massague. 1986. Transforming growth factor- $\beta$ stimulates the expression of fibronectin and collagen and their incorporation into the extracellular matrix. J. Biol. Chem. 261:4337-4345.

14. Fine, A., and R. H. Goldstein. 1987. The effect of transforming growth factor- $\beta$ on cell proliferation and collagen formation by lung fibroblasts. J. Biol. Chem. 262:3897-3902.

15. Penttinen, R. P., S. Kobayashi, and P. Bornstein. 1988. Transforming growth factor $\beta$ increases mRNA for matrix proteins both in the presence and in the absence of changes in mRNA stability. Proc. Natl. Acad. Sci. USA. 85:11051108.

16. Liu, J. M., and J. M. Davidson. 1988. The elastogenic effect of recombinant transforming growth factor-beta on porcine aortic smooth muscle cells Biochem. Biophys. Res. Commun. 154:895-901.

17. McGowan, S. E., and R. McNamer. 1990. Transforming growth factor- $\beta$ increases elastin production by neonatal rat lung fibroblasts. Am. J. Respir. Cell Mol. Biol. 3:369-376.

18. Foster, J., C. B. Rich, and J. R. Florini. 1987. Insulin-like growth factor I, somatomedin $\mathrm{C}$, induces the synthesis of tropoelastin in aortic tissue. Collagen Relat. Res. 7:161-169.

19. Foster, J. A., M. L. Miller, M. R. Benedict, R. A. Richman, and C. B. Rich. 1989. Evidence for insulin-like growth factor-I regulation of chick aortic elastogenesis. Matrix. 9:328-335.

20. Badesch, D., P. D. Lee, W. C. Parks, and K. R. Stenmark. 1989. Insulinlike growth factor I stimulates elastin synthesis by bovine pulmonary arteria smooth muscle cells. Biochem. Biophys. Res. Commun. 160:382-387.

21. McCarthy, T. L., M. Centrella, and E. Canalis. 1989. Regulatory effects of insulin-like growth factors I and II on bone collagen synthesis in rat calvarial cultures. Endocrinology. 124:301-309.

22. Kahari, V.-M., J. Heino, and E. Vuorio. 1987. Interleukin 1 increases collagen production and mRNA levels in cultured skin fibroblasts. Biochim. Biophys. Acta. 929:142-147.

23. Goldring, M. B., and S. M. Krane. 1987. Modulation by recombinant interleukin 1 of synthesis of types I and III collagens and associated procollagen mRNA levels in cultured human cells. J. Biol. Chem. 262:16724-16729.

24. Blatti, S. P., D. N. Foster, G. Ranganathan, H. L. Moses, and M. J. Getz. 1988. Induction of fibronectin gene transcription and mRNA is a primary response to growth-factor stimulation of AKR-2B cells. Proc. Natl. Acad. Sci. USA. 85:1119-1123.

25. Franceschi, R. T., C. J. Linson, T. C. Peter, and P. R. Romano. 1987. 
Regulation of cellular adhesion and fibronectin synthesis by 1a, 25-dihydroxyvitamin $D_{3}$. J. Biol. Chem. 262:4165-4171.

26. Cjaga, M. J., F. R. Weiner, M. Eghbali, M. A. Gimbrone, Jr., M. Eghbali, and M. Zern. 1987. Differential effects of $\gamma$-interferon on collagen and fibronectin gene expression. J. Biol. Chem. 262:13348-13351.

27. Botney, M. D., L. R. Kaiser, J. D. Cooper, R. P. Mecham, J. Roby, and W. C. Parks. 1992. Extracellular matrix protein gene expression in atherosclerotic pulmonary arteries. Am. J. Pathol. 142:357-364.

28. Watts, A. G., and L. W. Swanson. 1989. Combination of in situ hybridization with immunohistochemistry and retrograde tract-tracing. Methods Neurosci. 1:127-151.

29. Prosser, I. W., K. R. Stenmark, M. Suthar, E. C. Crouch, R. P. Mecham and W. C. Parks. 1989. Regional heterogeneity of elastin and collagen gene expression in intralobar arteries in response to hypoxic pulmonary hypertension as demonstrated by in situ hybridization. Am. J. Pathol. 135:1073-1087.

30. Kornblihtt, A. R., K. Umezawa, K. Vibe-Pederson, and F. E. Baralle. 1985. Primary structure of human fibronectin: differential splicing may generate at least 10 polypeptides from a single gene. EMBO (Eur. Mol. Biol. Organ.) J. 4:1755-1759.

31. Chu, M.-L., J. C. Myers, M. P. Bernard, J. G. Ding, and F. Ramirez. 1982. Cloning and characterization of five overlapping cDNAs specific for the human pro $\alpha 1$ (I) collagen chain. Nucleic Acids Res. 10:5925-5934.

32. Yamauchi, K., Y. Martinet, and R. G. Crystal. 1987. Modulation of fibronectin gene expression in human mononuclear phagocytes. J. Clin. Invest. 80:1720-1727.

33. Adachi, K., K. Yamauchi, J. F. Bernaudin, P. Fouret, V. J. Ferrans, and R. G. Crystal. 1988. Evaluation of fibronectin gene expression by in situ hybridization. Am. J. Pathol. 133:193-203.

34. Rabinovitch, M., W. Gamble, A. Nadas, O. S. Miettinen, and L. Reid. 1979. Rat pulmonary circulation after chronic hypoxia: hemodynamic and structural features. Am. J. Physiol. 236:H818-H827.

35. Meyrick, B., and L. Reid. 1980. Hypoxia-induced structural changes in the media and adventitia of the rat hilar pulonary artery and their regression. Am. J. Pathol. 100:151-178.

36. McKenzie, J. C., and R. M. Klein. 1983. Stimulation of protein synthesis in the rat pulmonary artery trunk during the early development of hypoxia-induced pulmonary hypertension. Blood Vessels. 20:283-294.

37. Kerr, J. S., D. J. Riley, M. M. Frank, R. L. Trelstad, and H. M. Frankel. 1984. Reduction of chronic hypoxic pulmonary hypertension in the rat by betaaminopropionitrile. J. Appl. Physiol. 57:1760-1766.

38. Mecham, R. P., L. A. Whitehouse, D. S. Wrenn, W. C. Parks, G. L. Griffin, R. M. Senior, E. C. Crouch, K. R. Stenmark, and N. F. Voelkel. 1987. Smooth muscle-mediated connective tissue remodeling in pulmonary hypertension. Science (Wash. DC). 237:423-426.

39. Nelken, N. A., S. R. Coughlin, D. Gordon, and J. N. Wilcox. 1991. Monocyte chemoattractant protein-1 in human atheromatous plaques. J. Clin. Invest. 88:1121-1127.

40. Yla-Herttuala, S., B. A. Lipton, M. E. Rosenfield, T. Sarkioja, T. Yoshimura, E. J. Leonard, J. L. Witztum, and D. Steinberg. 1991. Expression of monocyte chemoattractant protein 1 in macrophage-rich areas of human and rabbit atherosclerotic lesions. Proc. Natl. Acad. Sci. USA. 88:5252-5256.

41. Clark, R. A. F., N. E. Wickner, D. E. Doherty, and D. A. Norris. 1988. Cryptic chemotactic activity of fibronectin for human monocytes resides in the 120-kDa fibroblastic cell-binding fragment. J. Biol. Chem. 263:12115-12123.

42. Senior, R. M., G. L. Griffin, and R. P. Mecham. 1980. Chemotactic activity of elastin-derived peptides. J. Clin. Invest. 66:859-862.

43. Postlethwaite, A. E., and A. H. Kang. 1976. Collagen- and collagen peptide-induced chemotaxis of human blood monocytes. J. Exp. Med. 143:12991307.

44. Pacifici, R., C. Basilico, J. Roman, M. M. Zutter, S. A. Santoro, and R. McCracken. 1992. Collagen-induced release of interleukin-1 from human blood mononuclear cells. Potentiation by fibronectin binding to the $\alpha 5 \beta 1$ integrin. $J$. Clin. Invest. 89:61-67. 